\title{
MULTI-COMPONENT VARIABILITY OF PULSATING VARIABLE STARS OF RV TAURI TYPE
}

\author{
L.S. Kudashkina \\ Department of Mathematics, Physics and Astronomy, Odessa National Maritime University, \\ Ukraine,kuda2003@ukr.net
}

\begin{abstract}
For the group of pulsating variable stars with multi-component variability - which are currently classified as the RV Tau-type stars - the classification based on complexity of the periodograms is discussed. Periodograms were computed using the least approximation of the data with a sinusoid. The periodograms previously classified by their shape into three groups according to the presence or absence of certain structures: two peaks in a 2:1 ratio, (biharmonic signal with two waves during a main period, or the phase curve is significantly asymmetric), the presence of satellites of these peaks at the periodogram indicating the result of modulation of characteristics of oscillations. Group I includes objects showing the periodogram typical for the RV-type stars, and the ratio of the periods of the two main peaks is indicated. These oscillations appear to be relatively stable during the observations. The Group II includes objects, the periodograms of which contain signs of multi-periodicity or, vice-versa, only one clear peak, instead of two. The presence of multiple peaks may be due to multiple periods, or due to variability of the main period. The Group III includes objects, the periodograms of which are highly noisy, mainly due to a small number of observations or they do not show typical structures of RVtype stars. Such stars may be classified in the catalogue wrongly, so, additional study is needed. For periodogram analysis, the photometric observations from the international databases of AFOEV, AAVSO and ASAS were used. A least squares method is used for the analysis, to compare the variance in the deviations from the smoothed function with the variance in the initial observations. The mean light curves and the phase plane diagrams " $d x_{C}(\phi) / d \phi^{\prime \prime}$ vs " $x_{C}(\phi)$ " was compiled and analyzed for the values of the periods corresponding to the peaks in the periodograms.
\end{abstract}

Keywords: pulsating variable stars, periodogram analysis, phase plane diagrams

АНОТАЦІЯ. Для групи пульсуючих змінних зір із багатокомпонентною змінністю - зір, шо наразі віднесені до зір типу RV Tau - обговорюється класифікація на основі складності періодограм. Періодограми були обчислені із використанням апроксимації сигналу синусоїдою методом найменших квадратів Вони попередньо були класифіковані за своєю формою у три групи за наявністю або відсутністю певних структур: два піки у співвідношенні 2:1 (бігармонійний сигнал із двома хвилями за основний період, або фазова крива блиску суттєво асиметрична), наявність “супутників” цих піків на періодограмі, що вказує на результат модуляції характеристик коливань із довшим періодом. Група I включає об'єкти, що показують періодограму, характерну для зір типу RV, і вказано співвідношення періодів двох основних піків, які є порівняно стабільними протягом спостережень. Група II включає об'єкти, періодограми яких містять ознаки багатоперіодичності або, навпаки, лише один чіткий пік, замість двох. Наявність кількох піків може бути пояснена не лише наявністю кількох різних періодів, а й змінами основного періоду із часом. До III групи належать об'єкти, періодограми яких сильно зашумлені, головним чином, завдяки невеликій кількості спостережень, або вони не демонструють типових структур зір типу RV. Такі об'єкти можуть бути класифіковані у каталозі хибно, й потрібні додаткові дослідження. Для періодограмного аналізу використовували фотометричні спостереження 3 міжнародних баз даних AFOEV, AAVSO та ASAS. Для аналізу використовується метод найменших квадратів для порівняння дисперсії відхилень від згладжуючої (синусоїдальної) функції з дисперсією початкових спостереженнь. Середні криві блиску та фазові діаграми $" d x_{C}(\phi) / d \phi^{\prime \prime}$ від " $x_{C}(\phi)$ " були складені та проаналізовані для значень періодів, що відповідають пікам у періодограмах.

\section{Introduction}

The multi-component variability of pulsating variable stars of the type of RV Tauri (RV-type) was studied by method of the mathematical modeling of signals. For periodogram analysis, the observations from the databases of AFOEV (ftp://cdsarc.u-strasbg.fr/pub/afoev), AAVSO (http://aavso.org) and ASAS (http://www.astrouw.edu.pl/asas) were used (Andronov et al., 1992; Andronov et al., 2013; Kudashkina, 2003). A description of working with these databases can be found, for example, in the articles (Andronov and Marsakova, 2006; Marsakova and Andronov, 2006; Marsakova and Andronov, 2007). The methods for determination of the characteristics of individual extrema are reviewed in the articles (Kudashkina and Rudnitskij, 1988; Andronov, 2005; Andronov et al., 2016; Andrych et al., 2017; Andrych and Andronov, 2019; Andrych, Andronov, Chinarova, 2020; Andrych et al., 2020). 


\section{Periodogram analysis of RV Tau-type stars}

A least squares method is used for the analysis, to compare the variance in the deviations from the smoothed function with the variance in the initial observations. The statistic

$$
S(f)=\frac{\sigma_{C}^{2}}{\sigma_{o}^{2}}=1-\frac{\sigma_{O-C}^{2}}{\sigma_{o}^{2}},
$$

is used as a test-function, where $O$ is the mean square deviation of the "observations" $O$ from the mean. $C$ corresponds to the "calculated" values and $O-C$, to the deviations of the "observed" values from the "calculated" ones (Andronov, 1994; Kudashkina, 2019; Andronov, 2020; Andronov et al. 2020).
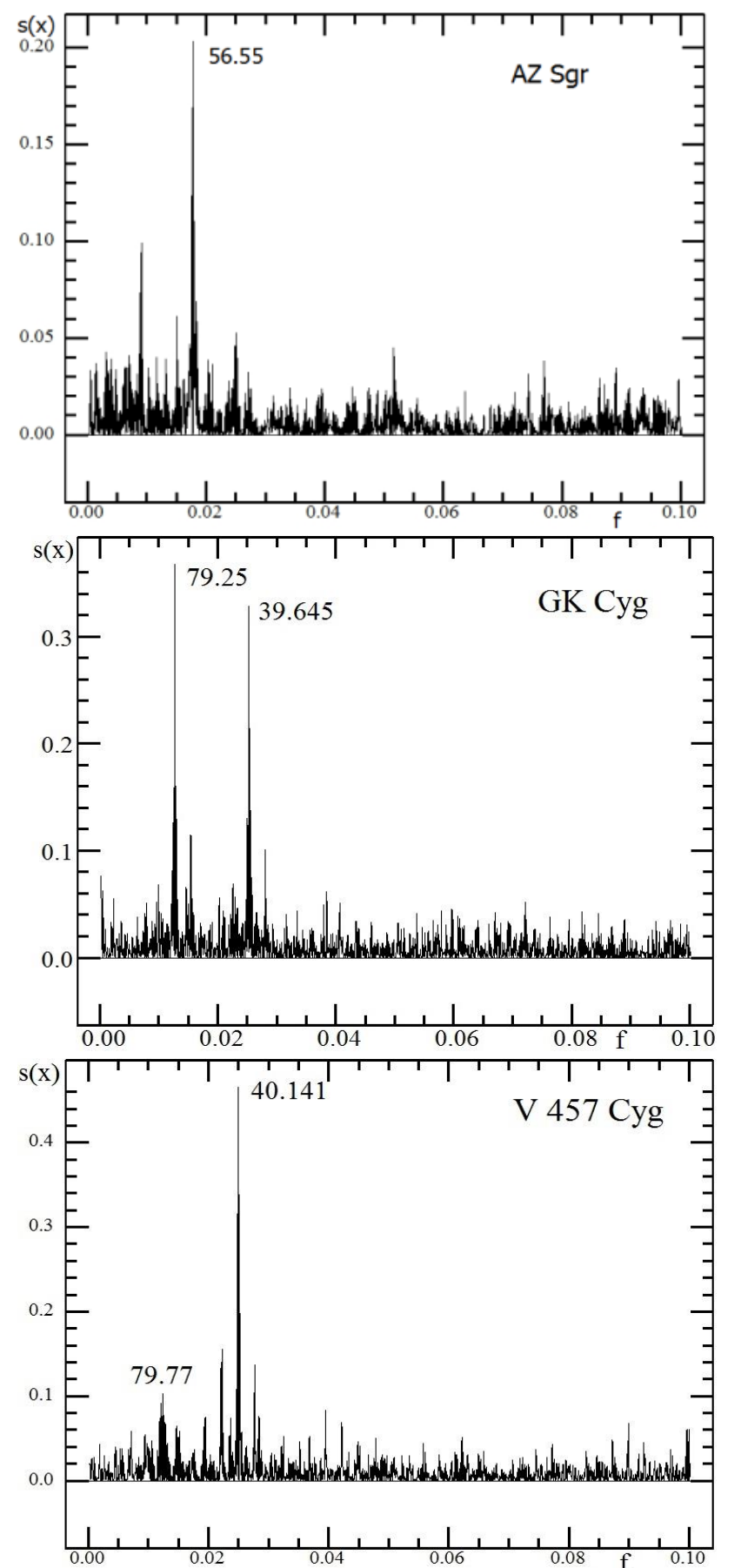

Figure 1: The periodograms for the RV Tau-type stars (from left to right) AZ Sgr, GK Cyg, and R Sge. All this stars are assigned to group I.
Figure 1, 2 show examples of the periodograms. The trial frequency $f=1 / P$ is shown at the horizontal axis, and the value of the test function $S(f)$ is shown at the vertical axis.

Periodograms are previously classified by their shape into three groups according to the presence or absence of certain structures: two peaks in a 2:1 ratio, the presence of satellites at these peaks indicating the result of beats (Kudashkina, 2020).

Group I includes objects showing the periodogram typical for the RV-type stars, and the ratio of the periods of the two main peaks is indicated. The Group II includes objects, the periodograms of which contain signs of multi-periodicity (Multi-p) or, vice-versa, only one clear peak (Single-p), instead of two. The Group III includes objects, the periodograms of which are highly noisy, mainly due to a small number of observations or they do not show typical structures of RV-type stars (figures 1-3).

Sometimes, semi-regular variables show two very different periods. This phenomenologically resembles intermediate polars, in which the two very distinct periods are seen, although they have different nature (Breus et al., 2012; Breus et al., 2013).

The mean light curves with the statistically best period, the approximations are computed using the program MCV (Andronov and Baklanov, 2004; Kudashkina and Andronov, 2010). These light curves are shown in the figure 4 . The characteristics of the mean light curves were calculated with the program FDCN (Andronov, 1994). These light curves are shown in the figure 5 (top). Further, phase portraits (Kudashkina and Andronov, 2017ab) were constructed: the magnitude are on the horizontal axis and its phase derivatives are on the vertical axis (figure 5 (bottom)).

It can also be assumed that in group 3 there are RV-type stars (or other types, for example, SR) that undergo a turbulent (stochastic) stage of self-oscillations before or after chaos.

Let some quantity $R$ be the ratio of two parameters:

$$
R=\mu / \gamma,
$$

where $\mu$ is responsible for the buildup of oscillations, and $\gamma$ for linear damping. With an increase in $R$, chaos occurs at a value of $R_{2}$, which is greater than the value of $R_{1}$, at which chaos disappears. A hysteresis region arises $R_{1}<R<R_{2}$, in which either a regime with equidistant spectra or turbulence is established (depending on the initial conditions) (Rabinovich, 1978).

Taking into account the studies of different authors, such objects can be attributed, for example, DF Cyg (Plachy, Bódi and Kolláth, 2018), R Sct (Veldhuizen and Percy, 1990), U Mon (Kudashkina, 2019), S Per (SRc) (Kudashkina, 1999; Kudashkina, 2012; Kudashkina and Rudnitskij, 1994), Y CVn (Kudashkina and Andronov, 2010), RX Boo (Andronov and Kudashkina, 1988).

In this regard, I would also like to draw attention to the star IW Car (Kudashkina, 2020) for which it was not possible to reliably identify a quasi-period typical for RV-type stars, perhaps, from the scarce data available for it. Actually, several values of the periods have been determined, however, the mean light curve can be calculated only according to the largest of them. 

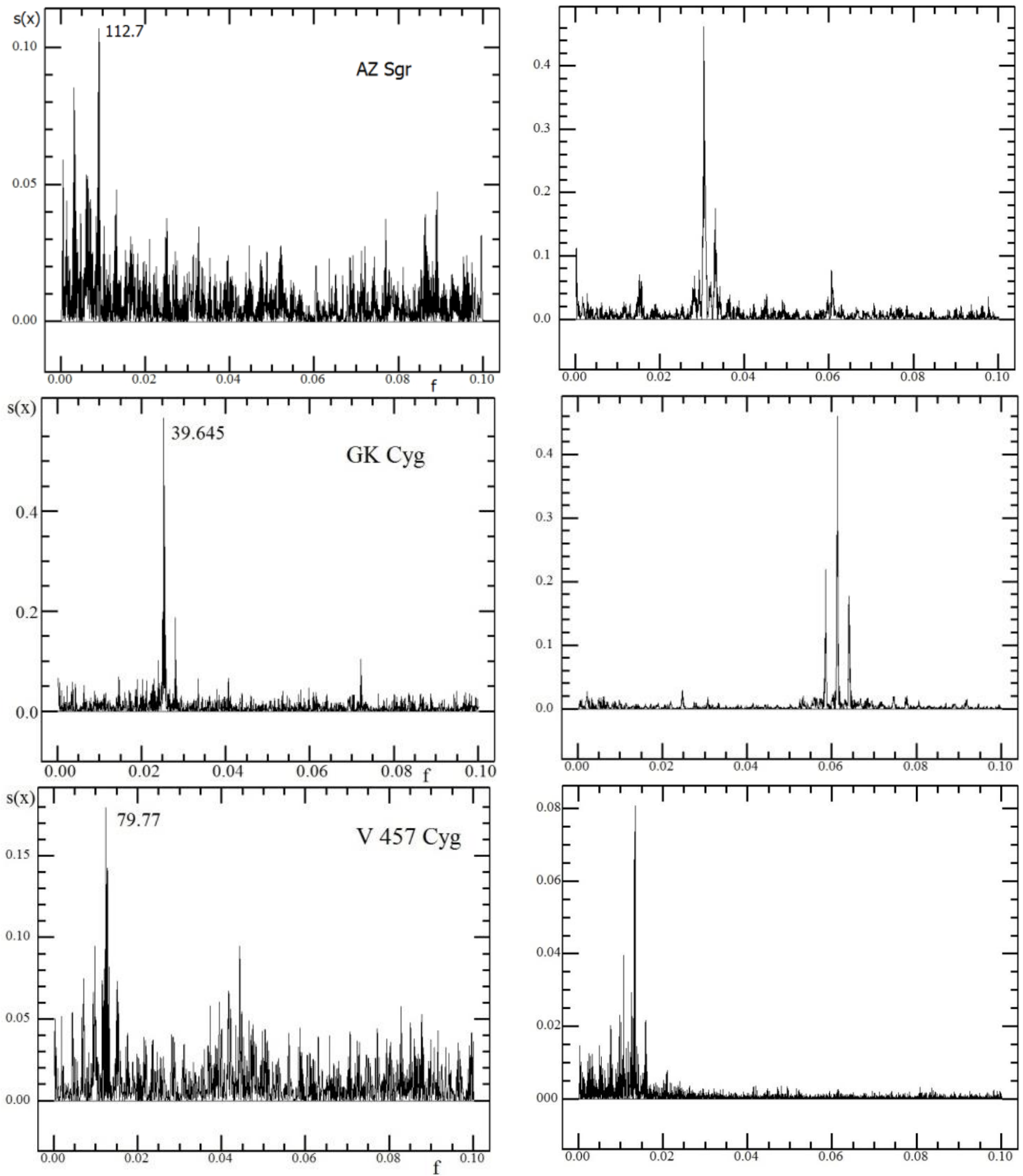

Figure 2: In these periodograms we have "prewhitened" the data by subtracting the contribution with a period corresponding to the highest peak in the figure 1 .

Figure 3: The periodograms for the RV Tau-type stars (from left to right) AD Aql, SZ Mon (group II) and TX Per (group III). 

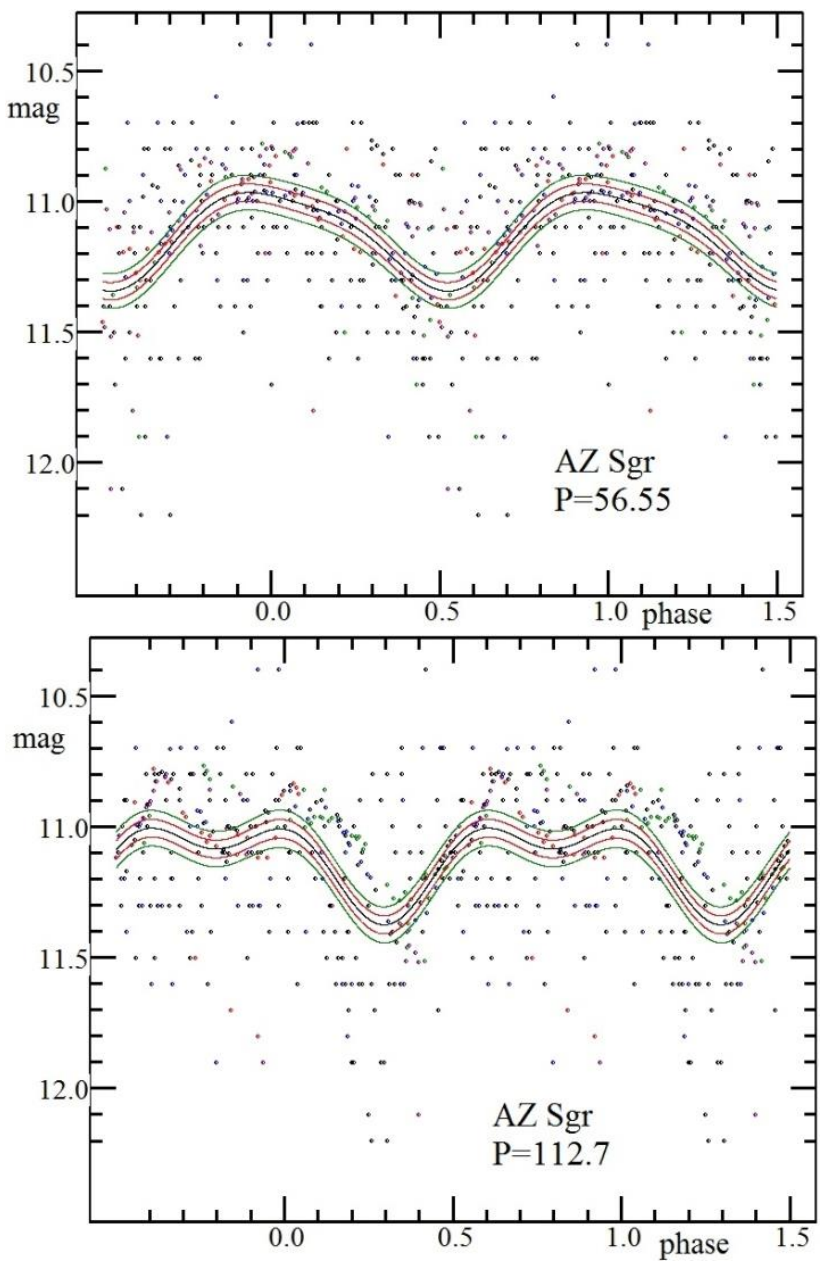

Figure 4: The mean light curve of AZ Sgr, obtained from observations by members AFOEV and ASAS. In all the figures of the light curves, the phase is set on the horizontal axis, and the brightness of the star is set on the vertical axis. The lines show the approximation and the corresponding $\pm 1 \sigma$ and $\pm 2 \sigma$ "error corridors".

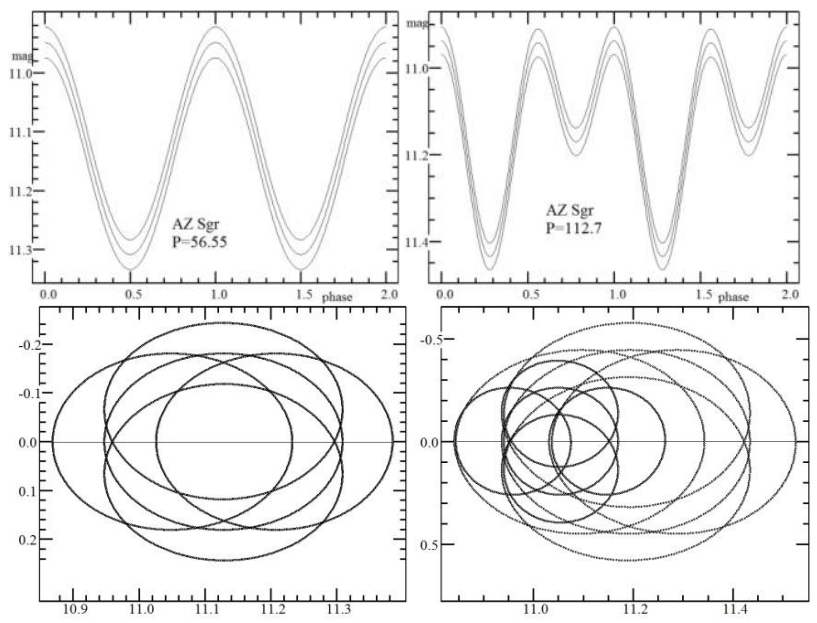

Figure 5: The mean light curves plotted with fundamental and formal periods and corresponding phase portraits for the AZ Sgr.
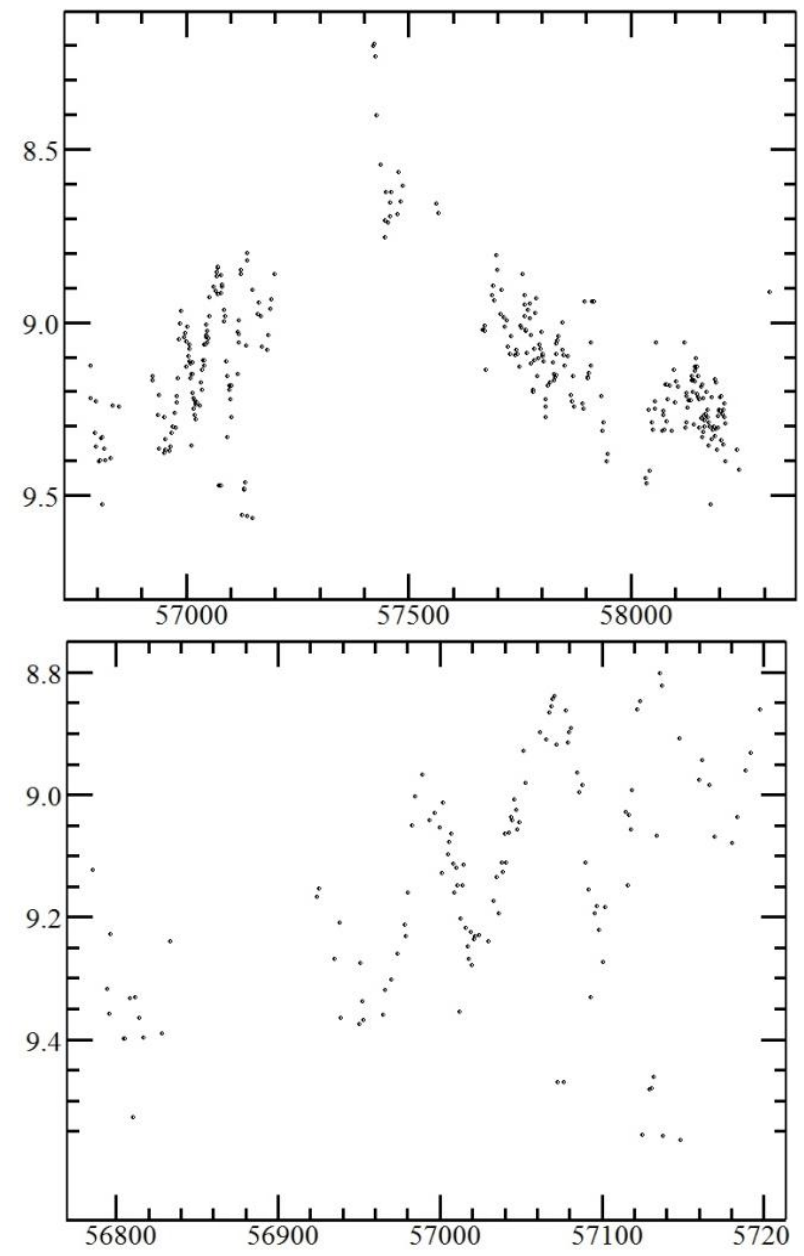

Figure 6: The light curve of IW Car obtained from observations by members ASAS (top). The "cyclic part" of the light curve (bottom).

Even if we divide the ASAS observations into two parts (completely "chaotic" and "cyclical") and carry out the periodogram analysis of the cyclic part separately, with the obtained value of the period $\mathrm{P}=68 \pm 2^{\mathrm{d}}$ it is impossible to calculate good mean light curve.

\section{Conclusion}

Thus,

1) from the form of the periodogram of IW Car, it can be assumed that it passes through the stage of stochastic self-oscillations, which then turn into chaotic ones.

2) The periodograms of several more stars have a similar form

3) All stars that have been studied show beats in frequency spectra.

4) For stars from groups I and II, periodograms clearly show two peaks with a ratio of $2: 1$.

The table 1 contains basic information about the studied stars and the results of periodogram analysis. 
Table 1. Characteristics of some studied RV stars.

\begin{tabular}{|c|c|c|c|c|c|c|}
\hline Star & Group* & $\mathrm{Sp}_{(\mathrm{GCVS})}$ & $\mathrm{P}_{\mathrm{GCVS}}, \mathrm{d}$ & $\mathrm{P}, \mathrm{d}$ & $\mathrm{P}_{2} / \mathrm{P}_{1}$ & $\mathrm{~N}$ (obs) \\
\hline AZ Sgr & I & $\begin{array}{c}\text { F5V: } \\
\text { F7-G0** }\end{array}$ & 113.6 & $\begin{array}{l}\mathrm{P}_{1}=56.54 \pm 0.02 \\
\mathrm{P}_{2}=112.7 \pm 0.1 \\
\mathrm{P}=6305 \pm 112 \\
\mathrm{P}=324 \pm 1\end{array}$ & 1.99 & 322 \\
\hline GK Cyg & I & & 79.75 & $\begin{array}{l}\mathrm{P}_{1}=39.645 \pm 0.005 \\
\mathrm{P}_{2}=79.25 \pm 0.03 \\
\mathrm{P}=26.423 \pm 0.008 \\
\mathrm{P}=22.831 \pm 0.006\end{array}$ & 2.00 & 223 \\
\hline V 457 Cyg & I & G0 & 79.08 & $\begin{array}{l}\mathrm{P}_{1}=40.141 \pm 0.006 \\
\mathrm{P}_{2}=79.77 \pm 0.05 \\
\mathrm{P}=107.2 \pm 0.1 \\
\mathrm{P}=75.45 \pm 0.07\end{array}$ & 2.01 & 238 \\
\hline AD Aql & II & $\mathrm{Fp}(\mathrm{R})$ & 66.03 & $\begin{array}{l}\mathrm{P}_{1}=33.045 \pm 0.003 \\
\mathrm{P}=5962 \pm 184 \\
\mathrm{P}_{2}=66.42 \pm 0.03 \\
\mathrm{P}=33.702 \pm 0.008\end{array}$ & 2.01 & 602 \\
\hline SZ Mon & II & F9-K5 & 32.685 & $\begin{array}{l}\mathrm{P}_{1}=16.3356 \pm 0.0006 \\
\mathrm{P}=466.1 \pm 2.4 \\
\mathrm{P}=16.265 \pm 0.003 \\
\mathrm{P}_{2}=32.64 \pm 0.01\end{array}$ & 2.00 & 1080 \\
\hline TX Per & III & $\begin{array}{l}\text { G5e-K0e } \\
\text { Gp(M2)- } \\
\text { K0e(M2) ** }\end{array}$ & 78. & $\begin{array}{l}\mathrm{P}=74.854 \pm 0.006 \\
\mathrm{P}=76.431 \pm 0.006 \\
\mathrm{P}=75.27 \pm 0.01 \\
\mathrm{P}=99.59 \pm 0.02\end{array}$ & & 5128 \\
\hline IW Car & III & $\begin{array}{c}\text { F7/8e } \\
\text { F7/8+ } \\
\text { A3/5Ib/II: ** }\end{array}$ & 72.1 & $\begin{array}{l}\mathrm{P}=1078 \pm 5 \\
\mathrm{P}=2308 \pm 80 \\
\mathrm{P}=276.7 \pm 0.9 \\
\mathrm{P}=71.6 \pm 0.1\end{array}$ & & 573 \\
\hline
\end{tabular}

* Kudashkina L. S., 2020

** https://www.aavso.org/vsx

\section{References}

Andronov I.L.: 1994, Odessa Astron. Publ., 7, 49-54. Andronov I.L., Baklanov A.V.: 2004, Astron. School's Rep., 5, 264-272. DOI:10.18372/2411-6602.05.1264.

Andronov I.L.: 2005, ASP Conf. Ser., 335, 37-53.

Andronov I.L.: 2020, Knowledge Discovery in Big Data from Astronomy and Earth Observation, $1^{\text {st }}$ Edition. Edited by Petr Skoda and Fathalrahman Adam. ISBN: 978-0-128-19154-5. Elsevier, 2020, p.191-224. DOI: https://doi.org/10.1016/B978-0-12-819154-5.00022-9.

Andronov I.L., Breus V.V., Kudashkina L.S.: 2020, arXiv preprint arXiv:2007.14264.

Andronov I.L., Chinarova L.L., Kudashkina L.S., Marsakova V.I., Tkachenko M.G.: 2016, ASP Conf. Ser., 505, 101.

Andronov I.L., Kudashkina L.S.: 1988, Astronomische Nachrichten, 309, Issue 5, 323-325. DOI: https://doi.org/ 10.1002/asna.2113090505 .

Andronov I.L., Kudashkina L.S., Grenishena L.V.: 2013, Częstochowski Kalendarz Astronomiczny, ed. Bogdan Wszołek, 9, 211-216.

Andronov I.L., Kudashkina L.S., Romanenko T.V.: 1992, Perem. Zvezdy, 23, 23-33.

Andronov I.L., Marsakova V.I.: 2006, Astrophysics, 49, no. 3, 370-385. DOI: https://doi.org/10.1007/s10511-006-0037-8.

Andrych K.D., Andronov I.L.: 2019, Open European Journal on Variable Stars, 197, 65-70.
Andrych K.D., Andronov I.L., Chinarova L.L.: 2017, Odessa Astron. Publ., 30, 57-62. DOI: https://doi.org/ 10.18524/1810-4215.2017.30.118521.

Andrych K.D., Andronov I.L., Chinarova L.L.: 2020, Journ. Phys. Studies, 24, No. 1, Article 1902, DOI: https://doi.org/10.30970/jps.24.1902.

Andrych, K.D., Tvardovskyi, D.E., Chinarova L.L., Andronov, I. L.: 2020, Contributions of the Astronomical Observatory Skalnaté Pleso, 50, no. 2, 557-559. DOI:10.31577/caosp.2020.50.2.557.

Breus V.V., Andronov I.L., Hegedus T., Dubovsky P.A., Kudzej I.: 2012, Advances in Astronomy and Space Physics, 2, 9-10. ADS: 2012AASP...2...9B.

Breus V.V., Andronov I.L., Dubovsky P., et al.: 2013, Journal of Physical Studies, 17, 3902. ADS: 2013JPhSt..17.3901B.

Kudashkina L.S.: 1999, Vestnik Odessa State Univ., 4, 55-58. Kudashkina L.S.: 2003, Kinematics and Physics of Celestial Bodies vol. 19, Issue 3, p. 193-233.

Kudashkina L.S.: 2012, Odessa Astron. Publ., 25/1, 18-20. Kudashkina L.S.: 2019, Astrophysics, 62, no. 4, 556-572.

Kudashkina L.S.: 2020, Annales Astronomiae Novae, 1, 199-204. Kudashkina L.S., Andronov I.L.: 2010, Odessa Astron. Publ., 23, 65-66. 
Kudashkina L.S.; Andronov I.L.: 2010, Odessa Astron. Publ., 23, 67-69.

Kudashkina L.S., Andronov I.L.: 2017a, Częstochowski Kalendarz Astronomiczny, ed. Bogdan Wszołek, 14, 283-290.; arXiv preprint: arXiv:1711.09029.

Kudashkina L. S., Andronov I. L.: 2017b, Odessa Astron. Publ., 30, 93-97.

Kudashkina L.S., Rudnitskij G.M.: 1994, Odessa Astron. Publ., 7/1, 66-69.

Kudashkina L.S., Rudnitskij G.M.: 1988, Perem. Zvezdy, 22, 925-926.
Marsakova V.I., Andronov I. L.: 2006, Astrophysics, 49, no. 4, 506-522. DOI: https://doi.org/ 10.1007/s10511006-0049-4.

Marsakova V.I., Andronov I.L.: 2007, Astrophysics, 50, no. 1, 76-82. DOI: https://doi.org/ 10.1007/s10511-0070008-8.

Plachy E., Bódi A. and Kolláth Z.: 2018, MNRAS, 481, 2986-2993. DOI: https://doi.org/10.1093/mnras/sty2511

Rabinovich M.I.: 1978, UFN, 125, no. 1, 123-177.

Veldhuizen T., Percy J. R.: 1990, JAAVSO, 18, 97-101. 